\title{
Research on the Training Mode of Product Design Talents Based on the Mode of Sino Foreign Cooperation in Running Schools
}

\author{
Weixiao Chen \\ Zhengzhou University of Aeronautics, Zhengzhou 450046, Henan, China.
}

Abstract: As an application-oriented major with strong practicality, product design specialty is oriented to cultivate compound senior professional and technical talents with solid scientific and technological foundation and artistic innovation ability, and pays attention to the system technology of efficiency and benefit research. Practice teaching occupies a large proportion for the traditional "inculcation" theoretical teaching mode has been unable to meet the needs of talents in the rapid changing of the market. At present, under the mode of Sino foreign cooperation in running schools, the effective integration of international talent outlook, quality views and high-quality education resources at home and abroad has greatly improved the quality and level of training for product design talents. This paper focuses on the issues related to the training mode of product design talents under the mode of Sino foreign cooperation in running schools.

Keywords: Mode of Sino Foreign Cooperation in Running Schools; Product Design; Talent Training Mode; Research

The mode of Sino foreign cooperation in running a school is a kind of educational institution which is take Chinese student as the object and jointly organized by domestic and foreign educational institutions. It is the product of China's education opening to the outside world and the rapid development of education. It speeds up the reform of our school running system, update the concept of talents, and broaden the channels of talent training as well as give full play to the high-quality education resources of home and abroad with remarkable effects. The product design talent training mode based on the Sino foreign cooperation mode will be discussed as follows.

\section{The importance of the application for the mode of Sino foreign cooperation in running schools in the development of colleges and universities}

Firstly, it is conducive to the cultivation of international talents. With the rapid development of world integration and economic globalization, how to cultivate high-quality talents who can stand in the fierce global market competition has become a common topic for all countries in the world. Especially with the deepening of China's opening to the outside world, the demand for international talents with compound and foreign-related characteristics is increasing. At present, colleges and universities apply the mode of Sino foreign cooperation in running schools to formulates advanced school running plans and flexible school running mechanisms, and cultivates talents who know well the rules of the international market and have the ability of international communication, in order to meet the needs of the market for talents with remarkable results.

Secondly, it is conducive to optimizing the talent training mode of domestic colleges and universities. Under the mode of Sino foreign cooperation in running schools, advanced educational resources from developed countries have been continuously introduced, which provides more choices for domestic education. It has a strong reference value and significance for the teaching and management of colleges and universities in China and is conducive to accelerating the transformation and upgrading of local colleges and Universities. Additionally, China's education market gradually opens, focusing on the

Copyright $\odot 2020$ Weixiao Chen

doi: $10.18686 /$ ahe.v4i10.2881

This is an open-access article distributed under the terms of the Creative Commons Attribution Non-Commercial License (http://creativecommons. org/licenses/by-nc/4.0/), which permits unrestricted non-commercial use, distribution, and reproduction in any medium, provided the original work is properly cited. 
cultivation of skilled and practical talents who meet the need of international market. This will not only help domestic colleges and universities to build their own brand, but also meet the demand of social development for talents, with obvious practical value.

Thirdly, it is conducive to promoting the reform of university management system and deepening academic innovation. Economic globalization has promoted the globalization of education to a great extent. The development of education among countries in the world is closely linked and mutually reinforcing. It also accelerates the integration of educational resources of various countries into the international community and promotes the development of transnational education. Moreover, under the mode of Sino foreign cooperation, the research cooperation is realized by colleges and universities at home and abroad, it pays attention to the integration of interdisciplinary resources, optimizes scientific research methods and equipment, and constantly deepens academic innovation with remarkable results.

\section{Development countermeasures of product design talents training mode based on Sino foreign cooperation in running schools}

\subsection{Accelerating the deep integration of domestic and foreign educational resources}

The key to the mode of Sino foreign cooperation in running schools is to optimize the training mode of domestic talents by making use of foreign high-quality educational resources, so as to cultivate internationalized and high-quality compound talents. However, due to the differences in political systems and economic development modes of different countries, there are great differences in educational concepts and operation as well as management mechanisms at home and abroad. Therefore, in Sino foreign cooperation in running schools, we should avoid copying foreign talent training models and strengthen the deep integration of domestic and foreign talent training modes. Such as learning from foreign advanced talent training objectives and programs, teaching methods, excellent curriculum and evaluation system, teaching management mechanism and so on, in order to coordinate with the domestic talent training mode. Based on this, domestic colleges and universities should combine the specific requirements of local economy and society for talents and their own advantages and characteristics, accelerate the localization of foreign high-quality college education resources, so as to cultivate international, compound and high-quality talents who not only master international standards and have international communication ability, but also meet the actual needs of domestic social and economic development.

\subsection{Design of product design talent training mode}

\subsubsection{Adhere to the product design as the center}

Specifically, in the teaching design, we should adhere to the product design as the core content of professional course and teaching activities, and strengthen the teaching of design methods, design performance, design psychology, product structure, materials, technology, computer-aided design, business model and other courses. Especially in the rapid development of Internet technology, we should attach great importance to the application of product design in the field of Internet, and strengthen interdisciplinary construction and course teaching. Other courses should be based on the product design course, pay attention to broaden the professional scope, so as to continuously expand the vision and knowledge of product design students.

\subsubsection{Based on the mode of Sino foreign cooperation}

Colleges and universities should pay attention to the establishment of perfect latent training objectives. Specifically speaking, it is necessary to combine the spirit of "Regulations on Sino Foreign Cooperation in Running Schools" and other documents to clarify the training objectives of product design talents under the mode of Sino foreign cooperation in running school according to the cooperative school running agreement. In another words, we should focus on the cultivation of compound applied talents of product design specialty who meet the needs of socialist modernization construction with international vision and innovative consciousness to meet the needs of industry development.

\subsubsection{Improving the four stages for product design talent training system}

By defining the talent training objectives of Sino foreign cooperation in running schools, a product design talent training system with four stages of the mode of Sino foreign cooperation in running schools is constructed based on the formulation of perfect talent training plan. Specifically, the first stage: clarify product design personnel training objectives and training specifications, improve the level of personnel training. The annual enrollment standards are formulated to ensure the quality of students. The training mode of " $2+2.5$ " is adopted. In the first two years, the required courses are completed in domestic colleges and universities, and in the third year, students are allowed to study in foreign cooperative colleges and complete credits as required, or cooperate with foreign colleges and universities after completion of four-year university courses in China for further study abroad. For example, university has signed a cooperation agreement with the Polish University of 
Social Sciences and humanities, the students will complete two years of university courses in China and then enter the Polish University of Social Sciences and humanities for in-depth study. The second stage: to build a perfect comprehensive curriculum system. When constructing the domestic teaching course system, the cross and broad features are focused. We should not only retain the traditional professional courses of domestic colleges and universities, but also learn the advantageous professional courses and characteristic courses of foreign cooperative colleges, so that students obtain more and more professional product design knowledge under the perfect course system. The third stage: pay attention to practice test. As product design is a practical and comprehensive major, under the mode of Sino foreign cooperation in running schools, domestic and foreign cooperative colleges and universities should cooperate to broaden teaching practice, such as carrying out design engineering software training projects, enterprise project field observation and training activities, so that the professional theoretical knowledge can be consolidated and understood by students in the practice process of participation, and practical ability, innovation ability and team cooperation ability are also strengthened to a large extent, so as to lay a solid foundation for the follow-up international design projects. The fourth stage: teaching feedback. Under the mode of Sino foreign cooperation in running schools, we should attach great importance to the stage of teaching feedback, set up a special working group for detecting the problems existing in teaching and formulating effective countermeasures for solution, in order to constantly improve the training mode of product design talents in practice.

\subsection{Building an international teaching team of "double qualified bilingual"}

Under the mode of Sino foreign cooperation in running schools, a perfect teaching staff is the basis and premise for improving the quality of talent training. At present, a "double teacher bilingual" teacher team need to be built. Although professional teachers in domestic colleges and universities and those in foreign cooperative colleges have solid knowledge foundation, high education background and strong English proficiency, they lack mutual understanding between Chinese and foreign teachers, as well as understanding of talent training objectives of other countries, teaching conditions and students' situation. Presently, the product design specialty under the mode of Sino foreign cooperation in running schools should pay attention to create a "double qualified bilingual" teaching team. On the one hand, the high-quality returnees should be introduced into the teaching team, and domestic and foreign professional scholars and industry elites are employed as parttime teachers in colleges and universities. On the other hand, we should strengthen the training of in-service teachers, such as organizing teachers to carry out further training in foreign cooperative institutions, deepening school enterprise cooperation mode, providing temporary training opportunities for teachers, and actively participating in national training programs, so as to continuously improve the teaching and scientific research ability of the teaching staff and provide service guarantee for the cultivation of high-quality compound applied talents.

\section{Conclusion}

To sum up, with the deepening of economic globalization, it is an important measure to cultivate international product design talents to implement the mode of Sino foreign cooperation in running schools. Based on this, colleges and universities should actively change the concept of education and teaching, promote the in-depth integration of excellent educational resources at home and abroad. The product design and talent training programs and implementation rules should be continuously improved to building an international teaching team of "double qualified bilingual", so as to lay a solid foundation for the cultivation of international and compound applied talents in line with the development needs of the global market.

\section{References}

1. Li H. Exploration and practice of Sino foreign cooperation in running schools and personnel training mode from the perspective of internationalization of higher education — Taking the Sino foreign cooperation of visual communication design major in Hefei Normal University as an example. Journal of Liuzhou Teachers College 2018; (3): 102-105.

2. Liu $\mathrm{W}, \mathrm{Wu} \mathrm{Z}$, Chen $\mathrm{Y}$, et al. Research on the quality supervision system of engineering management talents training mode under the background of Sino foreign cooperation in running schools. New Campus (First Ten Days) 2017; (3): 231-233.

3. Liu Z, Hu J. Research on the training mode of product design talents in undergraduate colleges from the perspective of work integrated learning. Vocational Education Forum 2014; (36): 32-34.

4. Zhang W. Research on the personalized training mode of industrial design talents in higher vocational colleges. Youth and Society: Middle 2014; (12): 55-56. 